\title{
KINERJA KLINIS SEBAGAI PREDIKTOR KEPUASAN PASIEN DENGAN MODERASI PRIORITAS KEGAWATAN PASIEN
}

\author{
Kshanti Adhitya ${ }^{1}$ \& Wisnu Untoro ${ }^{2}$ \\ ${ }^{1}$ RS Ortopedi Prof. dr. R. Soeharso Surakarta, Indonesia, \\ ${ }^{2}$ Universitas Sebelas Maret Surakarta, Indonesia \\ ${ }^{1}$ Email: dhita2013@gmail.com
}

\begin{abstract}
Abstrak: Kinerja Klinis Sebagai Prediktor Kepuasan Pasien dengan Moderasi Prioritas Kegawatan Pasien. Tujuan penelitian ini menguji secara empiris kinerja klinis sebagai prediktor kepuasan pasien dengan moderasi triase. Penelitian ini menggunakan metode observasi cross sectional. Sampel penelitian ini adalah pasien, keluarga, pendamping sejumlah 479. Uji hipotesis dengan model regresi pengaruh langsung dan model pemoderasi dengan Moderated Regression Analysis (MRA). Pengujian hipotesis model pengaruh langsung menunjukkan bahwa tingkat kepuasan yang terjadi dapat dijelaskan $42,8 \%$ oleh seluruh prediktor. Hasil analisis MRA menunjukkan semua prediktor, variabel prioritas kegawatan, dan moderat secara bersama-sama berpengaruh terhadap kepuasan. Namun demikian variabel prioritas kegawatan pasien bukan merupakan variabel moderasi. Hipotesis pengaruh langsung prediktor kepuasan yaitu pelayanan perawat, pelayanan dokter, waktu tunggu berpengaruh signifikan terhadap kepuasan pasien didukung. Faktor registrasi dan instruksi pulang/lanjutan tidak berpengaruh terhadap kepuasan. Hipotesis prioritas kegawatan pasien sebagai pemoderasi pengaruh prediktor terhadap kepuasan pasien tidak didukung.
\end{abstract}

Kata kunci: kinerja klinis, kepuasan pasien, prioritas kegawatan, triase, IGD.

\begin{abstract}
Clinical Performance as Predictor of Patient Satisfaction with Moderation of Patient Priorities. This study objective is to determine satisfaction predictors of clinical performance with triage as moderation. This research utilizes cross sectional observation. The research subject was 479 which are the patients, families, patient confidants in the ED of Orthopedic Hospital Soeharso. The hypotheses are tested using regression analysis and moderated regression analysis (MRA) approach. The results depict the satisfaction level up to $42.8 \%$ by all predictors of clinical performance. MRA result concluded that the triage variable of the patient can not be moderating variable. Satisfaction predictor, i.e., nursing, physician, and the waiting time, significantly influences the patient satisfaction. Otherwise, Registration factors and advanced/discharge have no influence on satisfaction. Triage as moderating of patient satisfaction is not supported.
\end{abstract}

Keywords: clinical performance, patient satisfaction, emergency priority, triage, Emergency Department.

\section{PENDAHULUAN}

Pelayanan IGD merupakan tantangan bagi setiap RS untuk terus memperbaiki kualitas pelayanannya. IGD merupakan pelayanan satu atap yang beroperasi selama 24 jam dan menjadi pintu masuk pasien sehingga menjadi gambaran wajah pelayanan RS. Tatalaksana awal di IGD adalah proses triase yaitu proses pemilahan pasien berdasar prioritas kegawatan. Tata laksana kasus gawat darurat merupakan sebuah pekerjaan penuh tantangan dengan melalui kegiatan 


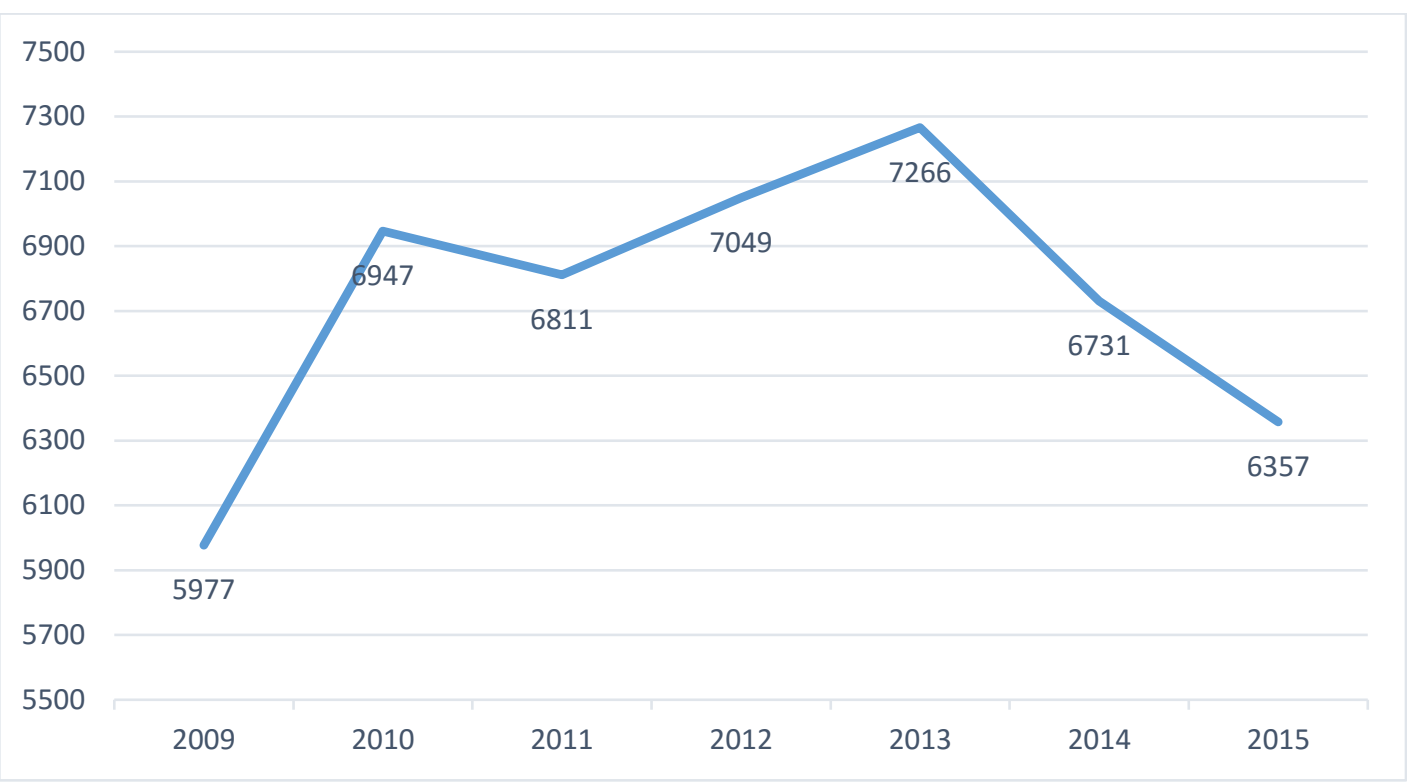

Gambar 1. Kunjungan IGD RS Ortopedi Prof. dr. R. Soeharso Surakarta (Sumber: Laporan Akuntabilitas Kinerja IGD RS Ortopedi Prof. dr. R. Soeharso Surakarta 2015)

yang saling berkaitan dimulai saat pasien masuk sampai pulang atau disposisi ke rawat inap. Pengelolaan manajemen kualitas memerlukan pengetahuan mengenai harapan pelanggan terhadap kualitas sehingga dapat dipakai dalam pembuatan kebijakan dan prosedur sesuai harapan. Mendefinisikan harapan terhadap kualitas merupakan hal kritis dalam manajemen operasional secara efektif dan efisien (Heizer et al., 2014). Penelitian ini akan memberikan gambaran respon time, variasi alur dan perbedaan karakteristik staf yang berhubungan dengan kinerja klinis dalam pelayanan IGD sehingga dapat mengidentifikasi faktor yang berperan dalam penentuan kepuasan pasien IGD dalam rangka mengidentifikasi faktor yang perlu diperbaiki untuk menjaga kualitas pelayanan IGD.

Data kunjungan dari Laporan Akuntabilitas Kinerja Instalasi Gawat Darurat (2015) RS Ortopedi Prof. dr. R. Soeharso dalam 3 tahun terakhir mengalami kecenderungan menurun. Adanya kecenderungan penurunan jumlah pasien IGD dan peningkatan jumlah pasien pulang paksa dalam 3 tahun terakhir berkaitan adanya sistem rujukan berjenjang dalam pelayanan asuransi kesehatan. Namun demikian pada berbagai referensi menyatakan bahwa penurunan kunjungan pasien dapat diakibatkan salah satunya akibat ketidakpuasan pasien. Tatalaksana awal dalam pelayanan IGD yaitu proses pemilahan pasien berdasar kegawatan pasien atau triase yang merupakan proses standar di IGD, sehingga baik secara langsung maupun tidak langsung dapat berpengaruh terhadap kepuasan pasien terhadap pelayanan IGD.

Penelitian oleh Boudreaux (2004), menyatakan faktor pelayanan staf perawat merupakan faktor prediktor terkuat dalam menentukan kepuasan pasien. Namun dinyatakan pula keterbatasan dalam penelitian ini yaitu adanya penentu kepuasan pasien IGD dapat berbeda berdasar sifat kegawatan pasien, kronisitas penyakit, maupun faktor pengalaman sebelumnya 
tentang kunjungan ke IGD. Penelitian menyarankan penelitian lanjutan dengan menentukan beberapa faktor yang terkait langsung maupun tidak langsung terhadap waktu tunggu dan terjadinya keterlambatan dengan mempertimbangkan sifat kegawatan pasien. Masalah penelitian ini yaitu apakah kinerja klinis yang berkaitan dengan registrasi, pelayanan perawat, pelayanan dokter, instruksi pulang/lanjutan, dan waktu tunggu memiliki pengaruh terhadap kepuasan pasien IGD yang dimoderasi oleh prioritas kegawatan (triase) pasien?

Tujuan penelitian ini adalah untuk menguji secara empiris indikator kinerja klinis yaitu proses registrasi, pelayanan perawat, pelayanan dokter, instruksi pulang/lanjutan dan waktu tunggu, dengan moderasi prioritas kegawatan (triase) pasien terhadap kepuasan pasien IGD di RS Ortopedi Prof. dr. R. Soeharso sebagai RS khusus dan RS Pendidikan.

Jay Heizer dan Barry Render (2014) menyatakan bahwa diferensiasi, biaya rendah dan respon yang cepat dapat dicapai saat manajer membuat keputusan operasi yang efektif dalam sepuluh wilayah manajemen operasi sehingga mampu mendukung misi dan menerapkan strategi. Pengelolaan kualitas membantu membangun strategistrategi sehingga sukses dalam diferensiasi, biaya rendah dan respon pelanggan. Perbaikan dalam kualitas akan membantu meningkatkan pangsa pasar dan menekan biaya, dan keduanya dapat meningkatkan profitabilitas. Peningkatan pangsa pasar sering terjadi karena perusahaan merespon secara cepat harga jual rendah sebagai hasil dari skala ekonomis, dan meningkatkan reputasi kualitas produk. Demikian juga, perbaikan kualitas akan diikuti oleh penurunan biaya karena perusahaan dapat meningkatkan produktivitas dan mengurangi kerja ulang, barang sisa dan biaya garansi. Dr. Provonost dalam The Wall Street Journal (Maret, 2011) menyatakan banyak kesalahan RS berkaitan dengan tidak adanya standardisasi, komunikasi yang buruk, dan budaya nonkolaborasi sebagai hal unik dan berbahaya. Padma, et al.(2010) berupaya untuk mengkonseptualkan kualitas pelayanan rumah sakit dengan komponen perspektif pasien dan keluarga serta menganalisis hubungan antara kualitas pelayanan dan kepuasan pelanggan. Hasil penelitian ini menunjukkan bahwa aspek pelayanan interpersonal adalah yang paling penting dalam memberikan kepuasan bagi pasien dan keluarga.

Kinerja (performance) menjadi isu dunia saat ini. Hal tersebut terjadi sebagai konsekuensi tuntutan masyarakat terhadap pelayanan prima dan bermutu tinggi. Mutu tidak terpisahkan dari standar, karena kinerja diukur berdasarkan standar. Kinerja berasal dari kata job performance atau actual performance yang berarti prestasi kerja atau prestasi sesungguhnya yang dicapai oleh seseorang. Performance atau kinerja merupakan hasil atau keluaran dari suatu proses (Nurlaila, 2010:71). Menurut pendekatan perilaku dalam manajemen, kinerja adalah kuantitas atau kualitas sesuatu yang dihasilkan atau jasa yang diberikan oleh seseorang yang melakukan pekerjaan (Luthans, 2005:165). Indikator untuk mengukur kinerja karyawan secara individu ada 6 indikator, yaitu: kualitas, kuantitas, ketepatan waktu, efektivitas, kemandirian, dan komitmen kerja (Robbins, 2006:260). 
Kajian literatur kepuasan pelanggan yang dilakukan Giese \& Cote (2000) sebagaimana dikutip Tjiptono \& Chandra (2011:292), terdapat 20 definisi yang diacu dalam riset kepuasan pelanggan selama periode waktu 30 tahun, meskipun definisi -definisi tersebut bervariasi, kedua pakar dari Washington State University ini menemukan kesamaan dalam hal tiga komponen utama, (1) Kepuasan pelanggan merupakan respon (emosional atau kognitif), (2) Respon tersebut menyangkut fokus tertentu (ekspektasi, produk, pengalaman konsumsi, dan seterusnya), (3) Respon terjadi pada waktu tertentu (setelah konsumsi, setelah pemilihan produk/jasa, berdasarkan pengalaman akumulatif, dan lain-lain). Trout (2000) melakukan tinjauan evidence based literature dimulai tahun 1976 sampai dengan Juli 1999 menyatakan bahwa penelitian oleh Hansagi (1992), Kurata JH (1992), Yarnold PR (1998), dan Matulich (1989) menyebutkan bahwa indikator kualitas pelayanan di IGD adalah kepuasan pasien. Meskipun kepuasan secara statistik mungkin tidak berhubungan dengan kualitas teknis pelayanan, namun berhubungan dengan konsep kualitas secara keseluruhan yang diterima oleh pasien. Persepsi ini menjadi dasar pasien untuk berkeinginan atau merekomendasikan pemilihan pelayanan IGD (Hostutler,1999). Sebagai bagian dari elemen pemasaran, kepuasan pasien menunjukkan peningkatan dalam hal kepatuhan pasien terhadap instruksi dokter saat perawatan lanjutan (Hostutler, 1999; Rydman RJ, 1999, Bjorvell H, 1991; Waggoner DM, 1981). Kepuasan pasien menurut Pohan (2007:144-154) diukur dengan indikator yaitu kepuasan terhadap akses, mutu, dan proses layanan kesehatan.
Kualitas memerlukan dibangunnya lingkungan manajemen kualitas total (total quality management) karena kualitas tidak dapat diperiksa dalam produk. Penentu kualitas pelayanan yaitu reliabilitas, tanggung jawab, kompetensi, akses, kewajiban, komunikasi, kredibilitas, keamanan, memahami, dan bersifat fisik (Heizer et al., 2014). Ekwall et al. (2008) melakukan penelitian prospective cross sectional menggunakan survei dan skala kepuasan konsumen emergensi menyatakan terdapat perbedaan kepuasan secara bermakna dalam persepsi tingkat kegawatan di antara pendamping pasien. Kepuasan lebih tinggi pada pendamping pasien dengan tingkat kegawatan tinggi dibanding tingkat kegawatan yang lebih rendah. Hasil ini terlepas dari pengaruh waktu tunggu atau pengetahuan pendamping pasien tentang status triase pasien.

Prioritas kegawatan pasien akan menentukan respon time di IGD, penentuan prioritas ini dikenal dengan sistem triase. Flemming (2009) menyebutkan triase dalam kamus medis Merriam Webster adalah proses pengambilan keputusan terhadap pasien mana yang harus diterapi lebih dulu berdasar penyakit dan beratnya cedera. Singapore General Hospital (2000) dalam panduan Triage Officer Course menyatakan definisi formal triase berasal dari kata "trier" dalam bahasa Perancis yang berarti membagi dalam 3 kelompok. Triase merupakan proses memilah pasien berdasar kebutuhan untuk tatalaksanan terapi medis. Jones et al. (2006) menyebutkan triase dilakukan di ruang gawat darurat, kondisi bencana, dan situasi perang ketika sumber daya medis dialokasikan untuk memaksimalkan jumlah pasien yang dapat 


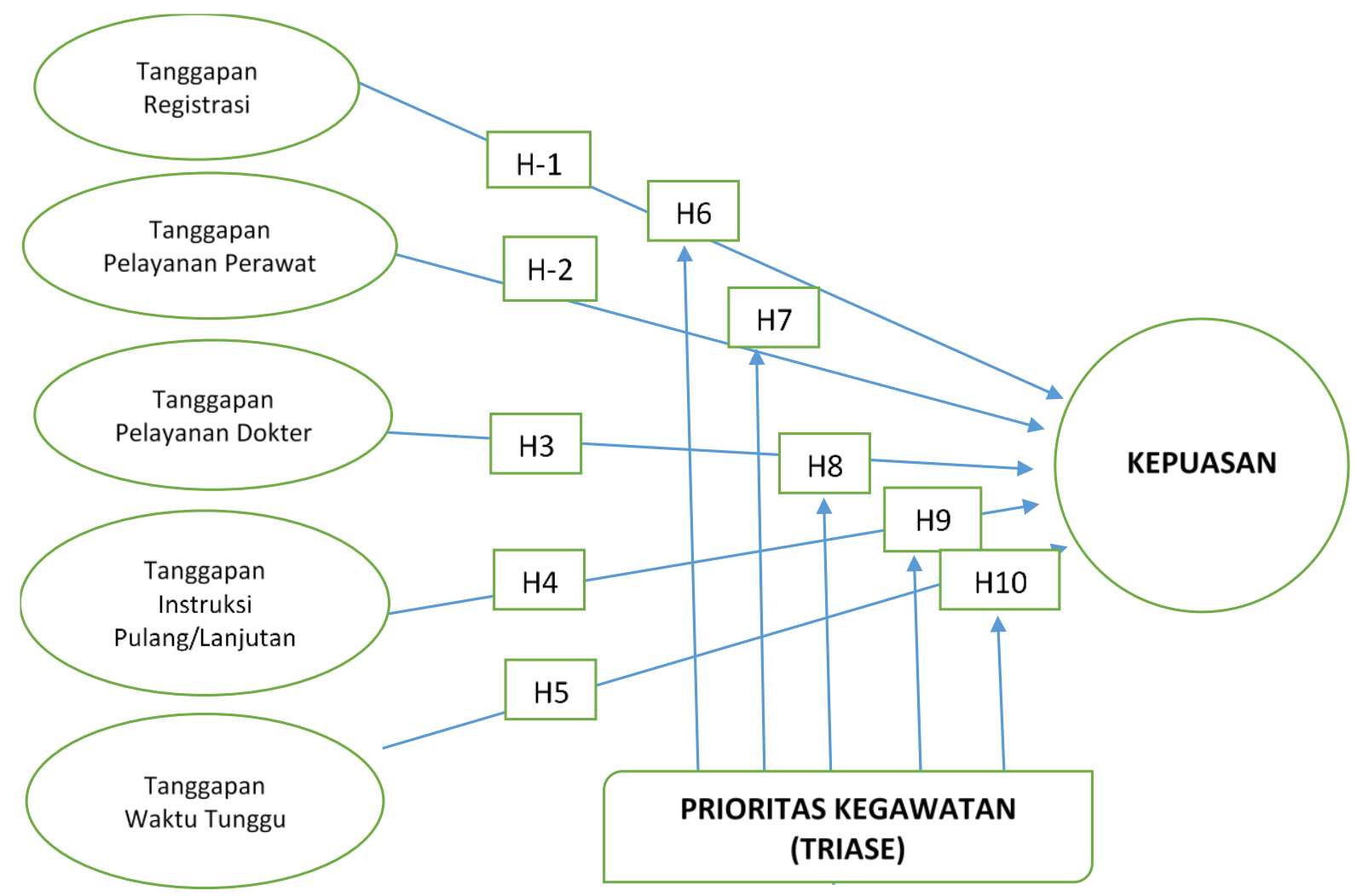

Gambar 2. Model Penelitian

diselamatkan. Triase adalah sebuah sistem manajemen risiko klinis di IGD di berbagai negara dalam tatalaksana pasien ketika dibutuhkan terapi yang melebihi kapasitas IGD. Terdapat 4 sistem klasifikasi triase yang sering dipakai yaitu prioritas 1 atau pasien kritis yang memerlukan resusitasi, prioritas 2 yaitu emergensi mayor atau urgen, prioritas 3 yaitu emergensi minor atau non urgen dan prioritas 4 yaitu non emergensi atau false emergency, dimana konsep ini sudah diaplikasikan dalam pelayanan IGD RS. Ortopedi Prof.dr.R.Soeharso Surakarta dengan menggunakan Patient Acuity Category (PAC) Scale. Sistem kategori triase yaitu menggunakan Patient Acuity Category Scale (PACS) yang terbagi dalam 4 prioritas yaitu (1) Prioritas 1, (2) Prioritas 2, (3) Prioritas 3 dan (4) Prioritas 4 false emergency atau non emergensi (RS Ortopedi, 2014).

\section{METODE}

Penelitian ini merupakan penelitian empiris dengan metode observasi cross sectional. Populasi penelitian ini adalah pasien, keluarga pasien, pendamping pasien yang berobat di IGD RS Ortopedi Prof dr R Soeharso Surakarta. Jumlah responden 486 yaitu seluruh pasien IGD pada shift pagi, siang, dan malam selama bulan Mei dan Juni 2016.

Hipotesis dalam penelitian ini terdapat 10 yaitu: (1) Tanggapan mengenai proses registrasi mempunyai pengaruh signifikan terhadap kepuasan pasien. (2) Tanggapan mengenai faktor pelayanan perawat mempunyai pengaruh signifikan terhadap kepuasan pasien. (3) Tanggapan mengenai faktor pelayanan dokter mempunyai pengaruh signifikan terhadap kepuasan pasien. (4) Tanggapan mengenai instruksi lanjutan dan pulang mempunyai pengaruh signifikan terhadap kepuasan pasien. (5) 
Tanggapan mengenai waktu tunggu mempunyai pengaruh signifikan terhadap kepuasan pasien (6) Prioritas kegawatan pasien memoderasi pengaruh tanggapan proses registrasi terhadap kepuasan. (7) Prioritas kegawatan pasien memoderasi pengaruh tanggapan pelayanan perawat terhadap kepuasan. (8) Prioritas kegawatan pasien memoderasi pengaruh tanggapan pelayanan dokter terhadap kepuasan. (9) Prioritas kegawatan pasien memoderasi pengaruh tanggapan instruksi pulang/lanjutan terhadap kepuasan. (10) Prioritas kegawatan pasien memoderasi pengaruh tanggapan waktu tunggu terhadap kepuasan.

Sarwono (2013) menyatakan indikator adalah variabel terobservasi/terukur secara langsung/variabel manifes yang digunakan untuk mengukur variabel laten yang tidak dapat diukur secara langsung. Konstruk adalah konsep yang tidak terobservasi/laten yang didefinisikan dalam istilah konseptual oleh peneliti, tetapi tidak dapat diukur secara langsung. Simbol dari variabel laten adalah oval, sedangkan simbol dari variabel observasi adalah kotak.

Format survei dengan menggunakan survei kepuasan kuesioner dari Boudreaux (2004) dengan modifikasi skala Linkert. Data diambil pada saat pasien akan dilakukan disposisi yaitu sebelum pulang rawat jalan atau sebelum pasien dipindahkan ke rawat inap. Responden adalah pasien atau keluarga/pendamping pasien. Eksklusi penelitian yaitu pada pasien prioritas 1 tanpa pendamping/keluarga, pasien/keluarga/ pendamping mengalami kendala bahasa, status tahanan polisi, gangguan psikiatri, dan menolak untuk berpartisipasi. Variabel yang digunakan dalam penelitian ini yaitu tanggapan terhadap proses registrasi, pelayanan perawat, pelayanan dokter, instruksi lanjutan/pulang, dan waktu tunggu sebagai variabel bebas, dengan tingkat kegawatan/triase sebagai variabel moderasi, dan kepuasan pasien sebagai variabel terikat.

Dalam penelitian ini, uji validitas menggunakan Confirmatory Factor Analysis (CFA) di mana setiap pertanyaan harus mempunyai faktor loading $>0,50$. Untuk analisis faktor, ukuran sampel yang direkomendasikan adalah tidak kurang dari 50 observasi, dan disarankan ukuran sampel 100 atau lebih. Sebagai aturan umum, beberapa peneliti merekomendasikan rasio 10:1 atau 20:1 kasus untuk setiap variabel (Hair, et al., 2006:98-99). Salah satu cara menentukan besaran sampel sesuai yang dirumuskan oleh Slovin. Instrumen dikatakan Tabel 1. Deskriptif Umur dan Waktu Tunggu Responden

\begin{tabular}{|c|c|c|c|c|c|}
\hline & & $\begin{array}{l}\text { umur responden } \\
\text { (tahun) }\end{array}$ & $\begin{array}{c}\text { waktu tunggu } \\
\text { registrasi (menit) }\end{array}$ & $\begin{array}{l}\text { waktu tunggu } \\
\text { periksa (menit) }\end{array}$ & $\begin{array}{c}\text { lama tinggal di IGD } \\
\text { (menit) }\end{array}$ \\
\hline \multirow{2}{*}{$\mathrm{N}$} & Valid & 463 & 479 & 479 & 458 \\
\hline & Missing & 16 & 0 & 0 & 21 \\
\hline Mean & & 37.25 & 6.88 & 8.04 & 138.48 \\
\hline Median & & 37.00 & 5.00 & 5.00 & 100.00 \\
\hline Minimum & & 13 & 3 & 3 & 15 \\
\hline Maximum & & 71 & 70 & 170 & 670 \\
\hline
\end{tabular}


valid berarti menunjukkan alat ukur yang dipergunakan untuk mendapatkan data itu valid atau dapat digunakan untuk mengukur apa yang seharusnya di ukur (Sugiyono, 2007).

Penelitian ini menggunakan uji reliabilitas dengan rumus Cronbach's Alpha. Sebelum pengujian regresi dilakukan, terlebih dahulu dilakukan uji asumsi klasik. Uji asumsi klasik meliputi uji normalitas, uji multikolinearitas, dan uji autokorelasi (Gujarati, 2006; Sunyoto, 2009).

Analisis data dengan metode analisis regresi linier berganda dengan bantuan program komputer SPSS for windows versi 20. Pengujian pengaruh kinerja klinis pada

kepuasan pasien dilakukan pengujian pengaruh langsung secara bersama sama kinerja klinis pada kepuasan pasien. Untuk pengujian digunakan Moderated Regression Analysis (Liana Lie, 2009; Sarwono J, 2013).

\section{HASIL DAN PEMBAHASAN}

Tabel 1 menunjukkan umur responden cukup bervariasi yaitu dengan umur tertua 71 tahun dan termuda 13 tahun, dengan rata-rata umur 37 tahun. Waktu tunggu selama proses registrasi minimum 3 menit dan maksimum 70 menit dengan rata-rata 6 menit, waktu tunggu sebelum pemeriksaan dokter minimum 3 menit dan maksimum 170 menit dengan rata-rata 8 menit, dan lama tinggal di Tabel 2. Deskripsi Karakteristik Responden

\begin{tabular}{clrr}
\hline No & \multicolumn{1}{c}{$\begin{array}{c}\text { Karakteristik } \\
\text { Responden }\end{array}$} & Jumlah & $\begin{array}{c}\text { Persentase } \\
(\%)\end{array}$ \\
\hline 1 & Jenis Kelamin & & \\
& Laki-laki & 264 & 55.1 \\
& Perempuan & 207 & 43.2 \\
& Jumlah & 479 & 100 \\
\hline 2 & Status Responden & & \\
& Keluarga & 360 & 75.2 \\
& Pasien & 99 & 20.7 \\
& Teman & 19 & 4 \\
& Jumlah & 479 & 100 \\
\hline 3 & Pekerjaan & & \\
& Lain & 171 & 35.7 \\
& PNS & 47 & 9.8 \\
& Swasta & 261 & 54.5 \\
& Jumlah & 479 & 100 \\
\hline 4 & Pendidikan & & \\
& D2 & 1 & 0.2 \\
& D3 & 29 & 6.1 \\
& S1 & 77 & 16.1 \\
& S2 & 11 & 2.3 \\
& S3 & 1 & 0.2 \\
& SD & 48 & 10 \\
& SMA & 192 & 40.1 \\
SMK & 3 & 0.6 \\
& SMP & 14 & 14 \\
& SPG & 1 & 0.2 \\
& Jumlah & 479 & 100 \\
\hline & & &
\end{tabular}


IGD minimum 15 menit dan maksimum 670 menit dengan rata-rata 138 menit.

Hasil pengumpulan data karakteristik responden diperoleh sejumlah 486 sampel, di mana 7 sampel eksklusi. Hasil penelitian pada tabel 2 menunjukkan responden terbanyak laki-laki (55\%), sebagian besar status responden sebagai keluarga pasien (75\%), pekerjaan swasta (54\%), dengan pendidikan terakhir SMA (40\%). Hal ini menunjukkan tidak terdapat perbedaan yang bermakna antara jenis kelamin, namun sebagian besar status responden sebagai keluarga menunjukkan keterlibatan keluarga dalam pengambilan keputusan pada kondisi gawat darurat.
Data karakteristik pasien pada tabel 3 menunjukkan sebagian pasien datang pada shift pagi (48\%), dengan menggunakan transportasi pribadi (75\%), pembiayaan umum (68\%), kondisi akhir rawat jalan (68\%) dengan prioritas kegawatan P2 (59\%).

Uji validitas dengan Confirmatory Factor Analysis (CFA) terdapat 18 item pertanyaan yang valid yaitu 3 item untuk tanggapan registrasi, 5 item untuk tanggapan pada perawat, 4 item untuk tanggapan pada dokter, 2 item untuk tanggapan pada instruksi, 2 item untuk tanggapan pada waktu tunggu dan 2 item kepuasan pasien.

Pengujian reliabilitas pada 6 variabel yang diteliti, yaitu tanggapan registrasi, tanggapan

Tabel 3. Deskriptif Karakteristik Pasien

\begin{tabular}{|c|c|c|c|}
\hline No & Karakteristik Pasien & Jumlah & Persentase (\%) \\
\hline \multirow[t]{5}{*}{1} & Shift & & \\
\hline & Malam & 71 & 14.8 \\
\hline & Pagi & 230 & 48 \\
\hline & Siang & 178 & 37.2 \\
\hline & Jumlah & 479 & 100 \\
\hline \multirow[t]{5}{*}{2} & Transportasi & & \\
\hline & Ambulance & 26 & 5.4 \\
\hline & Pribadi & 362 & 75.6 \\
\hline & Umum & 82 & 17.1 \\
\hline & Jumlah & 479 & 100 \\
\hline \multirow[t]{4}{*}{3} & Cara Bayar & & \\
\hline & JKN & 183 & 38.2 \\
\hline & Umum & 294 & 61.4 \\
\hline & Jumlah & 479 & 100 \\
\hline \multirow[t]{4}{*}{4} & Kondisi Akhir & & \\
\hline & MRS & 150 & 31.3 \\
\hline & Rawat Jalan & 328 & 68.5 \\
\hline & Jumlah & 479 & 100 \\
\hline \multirow[t]{6}{*}{5} & Triase & & \\
\hline & P1 & 9 & 1.9 \\
\hline & P2 & 283 & 59.1 \\
\hline & P3 & 173 & 36.1 \\
\hline & P4 & 14 & 2.9 \\
\hline & Jumlah & 479 & 100 \\
\hline
\end{tabular}


perawat, tanggapan dokter, tanggapan tingkat kepuasan yang terjadi dapat instruksi, tanggapan waktu tunggu dan dijelaskan 42,8\% seluruh variabel independen kepuasan memiliki nilai Cronbach alpha $>0,8$ kinerja klinis secara bersama-sama. Pada dan $<1$ yang berarti bahwa instrumen yang diteliti untuk mengungkap keenam variabel tersebut dinyatakan layak dijadikan instrumen dalam penelitian ini.

Uji normalitas dengan grafik histogram, didapatkan garis kurva normal demikian juga dari normal probability plots, menunjukkan berdistribusi normal karena garis (titik titik) mengikuti garis diagonal. Uji multikolinieritas menunjukkan model regresi dalam penelitian ini tidak ada masalah multikolinieritas. Uji autokorelasi dengan Durbin Watson menunjukkan tidak terjadi autokorelasi

Pada pengujian hipotesis model pengaruh langsung dengan metode analisis regresi berganda didapatkan pada tabel 4.

Pada pengujian hipotesis model pengaruh langsung dengan metode analisis regresi berganda didapatkan adjusted koefisien determinasi (Adj $R^{2}$ ) menunjukkan bahwa Anova (tes F) dengan tingkat signifikansi $0,000<0,05$ sehingga model regresi ini sudah layak digunakan untuk memprediksi tingkat kepuasan. Pada bagian koefisien regresi terlihat dengan uji t bernilai signifikan pada variabel independen tanggapan perawat, dokter, dan waktu tunggu, sedangkan tanggapan registrasi dan tanggapan instruksi pulang/lanjutan nilai $t$ tidak signifikan. Diperoleh hasil persamaan pada model pengaruh langsung (Persamaan 1).

Pada uji hipotesis dengan model pemoderasi didapatkan hasil adjusted koefisien determinasi (Adj $\mathrm{R}^{2}$ ) menunjukkan bahwa tingkat kepuasan yang terjadi dapat dijelaskan $43,3 \%$ seluruh variabel independen, variabel prioritas kegawatan dan moderat secara bersama-sama. Pada uji Anova (tes F) menghasilkan F hitung 32,798 dengan signifikansi 0,000 . Maka secara

Tabel 4. Ringkasan Hasil Pengujian Hipotesis

\begin{tabular}{lcccccc}
\hline \multirow{2}{*}{ Variabel Independen } & \multicolumn{3}{c}{ Model Pengaruh Langsung } & \multicolumn{3}{c}{ Model Pemoderasi } \\
\cline { 2 - 7 } & $\mathrm{B}$ & $\mathrm{t}$ & $\mathrm{Sig}$ & $\mathrm{B}$ & $\mathrm{t}$ & $\mathrm{Sig}$ \\
\hline (Constant) & 0,469 & 2,392 & 0,017 & 0,856 & 1,001 & 0,318 \\
Tanggapan Registrasi & 0,092 & 1,467 & 0,143 & 0,243 & 0,866 & 0,387 \\
Tanggapan Perawat & 0,235 & 3,155 & 0,002 & 0,107 & 0,334 & 0,738 \\
Tanggapan Dokter & 0,201 & 2,929 & 0,004 & 0,241 & 0,786 & 0,432 \\
Tanggapan Instruksi & 0,108 & 1,892 & 0,059 & 0,040 & 0,181 & 0,856 \\
Waktu Tunggu & 0,228 & 5,199 & 0,000 & 0,152 & 0,799 & 0,425 \\
Prioritas Kegawatan & & & & 0,162 & $-0,476$ & 0,634 \\
Moderat 1 & & & $-0,070$ & $-0,540$ & 0,589 \\
Moderat 2 & & & 0,044 & 0,425 & 0,671 \\
Moderat 3 & & & $-0,029$ & $-0,162$ & 0,871 \\
Moderat 4 & & & 0,023 & 0,752 & 0,752 \\
Moderat 5 & & & 0,029 & 0,669 & 0,669 \\
\hline R2 & 0,434 & & 0,436 & & \\
Adj R2 & 0,428 & & 0,423 & & \\
F test & 72,597 & & 32,798 & & \\
Sig F & 0,000 & & & 0,000 & & \\
\hline
\end{tabular}

Variabel Dependen: Kepuasan 
bersama-sama variabel independen dan variabel prioritas kegawatan dan moderat berpengaruh terhadap tingkat kepuasan. Pada bagian koefisien regresi terlihat dengan uji $\mathrm{t}$ bernilai tidak signifikan pada seluruh variabel independen, variabel prioritas kegawatan, dan moderat.

Hasil penelitian ini tidak mendukung penelitian cross sectional oleh Yarnold (1998) yang menyatakan bahwa perhatian dari staf RS dan penjelasan mengenai prosedur selain perhatian dari dokter dan lama waktu tunggu, berpengaruh terhadap kepuasan pasien. Pada penelitian ini analisis penilaian tanggapan mengenai proses registrasi meliputi faktor kesopanan petugas, petugas yang memperhatikan kerahasiaan selama pendaftaran dan kemudahan dalam pembiayaan. Dalam kondisi gawat darurat proses registrasi tidak berperan dalam persepsi kepuasan pasien IGD kemungkinan karena jumlah pasien yang sedikit dan kebijakan kemudahan prosedur, selain itu fokus utama keluarga/pendamping dan pasien lebih kepada hal yang terkait langsung dalam terapi penyakitnya. Hal ini mungkin berbeda pada situasi IGD yang lebih ramai. Dari pembahasan di atas hipotesis 1 yaitu tanggapan pada proses registrasi berpengaruh terhadap kepuasan pasien tidak didukung.

Hasil penelitian ini mendukung penelitian oleh Boudreaux (2004) yang menyebutkan pelayanan perawat/staf RS berpengaruh signifikan terhadap kepuasan pasien. Penelitian mengenai kepuasan pasien di Iran oleh Zia TS et al.(2011) menyatakan terdapat hubungan signifikan antara kepuasan pasien terhadap pelayanan medis dan perawat dan jadwal shift. Pelayanan dan perilaku staf yang paling banyak bersentuhan dengan pasien dan keluarga adalah profesi perawat, sehingga hal ini akan mempengaruhi persepsi kepuasan terhadap pelayanan IGD secara keseluruhan. Dari pembahasan di atas hipotesis 2 yaitu tanggapan pada pelayanan perawat berpengaruh terhadap kepuasan pasien didukung.

Penelitian oleh Tacoh TS et al.(2013) menunjukan bahwa dimensi ketanggapan, kehandalan, jaminan, kepedulian dan bukti langsung dan kepuasan pasien. Hasil penelitian ini mendukung penelitian oleh Hall (1996) dan Yarnold (1998) bahwa perhatian dan pelayanan oleh dokter berpengaruh signifikan terhadap kepuasan pasien. Penelitian oleh Bursch (1993) menyatakan terdapat 14 faktor pelayanan berhubungan dengan kepuasan secara keseluruhan. Lima faktor tertinggi yaitu waktu tunggu, pelayanan perawat, staf IGD, pelayanan dokter, dan pemberian informasi. Meskipun berbagai metode penelitian berbeda namun banyak penelitian konsisten menyatakan faktor pelayanan dokter berpengaruh signifikan terhadap kepuasan, hal ini dapat dipahami di mana posisi dokter merupakan staf yang kontak langsung dan memberi keputusan medis sesuai kondisi pasien. Dari pembahasan di atas hipotesis 3 yaitu tanggapan pada pelayanan dokter berpengaruh terhadap kepuasan pasien didukung.

Fokus proses pelayanan pada kepuasan pasien dan interaksi medis, sosial dan psikologis antara pasien dan praktisi rumah sakit. Beberapa peneliti menyatakan bahwa kepuasan pasien tidak hanya pada kualitas pelayanan, tetapi juga niat dari pasien untuk menggunakan jasa rumah sakit (Padman, 
Rajendran dan Lokachari, 2010). Hasil penelitian ini mendukung penelitian oleh Trout (2000) menyatakan beberapa penelitian menunjukkan adanya kepuasan pasien akan menunjukkan peningkatan kepatuhan pasien terhadap instruksi saat pulang. Dalam penelitian ini instruksi lanjutan/pulang terhadap pasien tidak berpengaruh terhadap kepuasan pasien. Dari pembahasan di atas hipotesis 4 yaitu tanggapan pada instruksi lanjutan/pulang berpengaruh terhadap kepuasan pasien tidak didukung.

Hasil analisis menunjukkan bahwa tanggapan mengenai waktu tunggu berpengaruh signifikan terhadap kepuasan pasien. Faktor yang dianalisis berkaitan dengan waktu tunggu saat proses pendaftaran dan waktu tunggu pemeriksaan oleh dokter. Salah satu mutu pelayanan yang menjadi keluhan masyarakat adalah berkaitan dengan waktu tunggu di IGD baik dalam proses administrasi maupun pertolongan medis oleh staf dokter maupun perawat. Hasil tersebut mendukung penelitian oleh Bursch (1993), Hall (1996), dan Hedges JR et al (2002) menyatakan bahwa persepsi pasien terhadap waktu tunggu berhubungan secara konsisten dengan kepuasan pasien secara keseluruhan. Dari pembahasan di atas hipotesis 5 yaitu tanggapan pada waktu tunggu berpengaruh terhadap kepuasan pasien didukung.

Hasil analisis menunjukkan bahwa prioritas kegawatan pasien bukan sebagai pemoderasi pengaruh tanggapan registrasi terhadap kepuasan pasien. Belum ada penelitian sebelumnya tentang kategori triase/prioritas kegawatan pasien sebagai variabel moderasi. Hasil dari penelitian ini dengan setting RS Ortopedi sebagai RS Pendidikan dan RS rujukan tingkat 3 kemungkinan turut berperan dalam penentu tingkat kepuasan pasien. Sebagai RS rujukan tingkat 3 pasien pada prioritas kegawatan tertinggi yang mengancam nyawa memiliki proporsi terendah karena kebanyakan pasien dirujuk dalam keadaan stabil sesuai standar keselamatan pasien dan disertai dengan kelengkapan administrasi. Selain itu standar prosedur dalam penanganan kegawatan dengan prioritas tinggi akan mendapat prioritas sumber daya termasuk berkaitan dengan prosedur administrasi. Dari pembahasan di atas hipotesis 6 yaitu prioritas kegawatan pasien sebagai pemoderasi pada pengaruh tanggapan proses registrasi terhadap kepuasan pasien tidak didukung.

Hasil analisis menunjukkan bahwa prioritas kegawatan pasien bukan sebagai pemoderasi pengaruh tanggapan pelayanan perawat terhadap kepuasan pasien. Pasien dengan prioritas kegawatan yang tinggi maupun rendah secara prosedur standar diberikan pelayanan keperawatan sesuai prosedur, hal ini kemungkinan karena jumlah pasien di RS Ortopedi Prof. dr. R. Soeharso tidak sebanyak pasien di RS Umum dengan variasi kasus yang banyak dalam waktu yang bersamaan. Hal ini tidak mendukung penelitian oleh Lewis et al.(1992) menyatakan terdapat perbedaan tingkat kepuasan berdasar kategori triase, pelayanan perawat, pelayanan dokter, lingkungan, staf, waktu tunggu dan informasi. Dari pembahasan di atas hipotesis 7 yaitu prioritas kegawatan pasien sebagai pemoderasi pada pengaruh tanggapan pelayanan perawat terhadap kepuasan pasien tidak didukung. 
Hasil analisis menunjukkan bahwa kontribusi positif terhadap kepuasan pasien. prioritas kegawatan pasien bukan sebagai pemoderasi pengaruh tanggapan pelayanan dokter terhadap kepuasan pasien. Pelayanan IGD merupakan pelayanan yang bersifat unik dan menjadi pintu masuk pasien dengan pelayanan 24 jam. Pada RS dengan jumlah kunjungan yang tidak banyak dengan jumlah sumber daya mencukupi maka proses triase bisa berjalan secara optimal, sehingga pasien yang berada dalam prioritas tinggi maupun rendah akan mendapatkan pelayanan dokter secara optimal. Hal ini tidak mendukung penelitian oleh Hansagi (1992) yang menyatakan bahwa kegawatan kondisi pasien berpengaruh terhadap kepuasan pasien. Tidak ada korelasi antara kepuasan keseluruhan dengan tingkat kepuasan spesifik dan kepuasan keseluruhan. Dari pembahasan di atas hipotesis 8 yaitu prioritas kegawatan pasien sebagai pemoderasi pada pengaruh tanggapan pelayanan dokter terhadap kepuasan pasien tidak didukung.

Hasil analisis menunjukkan bahwa prioritas kegawatan pasien bukan sebagai pemoderasi pengaruh tanggapan instruksi pulang/lanjutan terhadap kepuasan pasien. Pada RS dengan jumlah kunjungan yang tidak banyak dengan jumlah sumber daya mencukupi maka proses triase bisa berjalan secara optimal, sehingga pasien yang berada dalam prioritas tinggi maupun rendah akan mendapatkan penjelasan dalam hal instruksi pulang/lanjutan secara baik. Belum ada penelitian yang mengkaitkan pelaksanaan sistem triase dengan pengaruhnya dalam pemberian instruksi pulang/lanjutan terhadap kepuasan pasien. Penelitian oleh Trout (2000) menyebutkan bahwa komunikasi penyedia layanan memberi Dari pembahasan di atas hipotesis 9 yaitu prioritas kegawatan pasien sebagai pemoderasi pada pengaruh tanggapan instruksi pulang/lanjutan terhadap kepuasan pasien tidak didukung.

Sistem triase secara prosedur memiliki implikasi terhadap perbedaan waktu tunggu sesuai prioritas kegawatan, namun dengan pelaksanaan yang sesuai standar dan komunikasi yang baik terbukti pada penelitian ini bahwa triase tidak memoderasi pengaruh tanggapan waktu tunggu terhadap kepuasan pasien. Secara garis besar menunjukkan pasien/keluarga/pendamping memahami adanya tatalaksana sesuai skala prioritas dalam pelayanan gawat darurat. Berbagai penelitian sebelumnya oleh Taylor (2004) dan Hansagi et.al. (1992) menyatakan bahwa waktu tunggu merupakan faktor yang mempengaruhi secara signifikan terhadap kepuasan pasien IGD. Pelaksanaan sistem triase sesuai standar akan memberi implikasi terhadap perbedaan waktu tunggu sesuai prioritas kegawatan pasien. Salah satu tujuan dari pelaksanaan sistem triase adalah tercapainya kepuasan pasien. Hasil penelitian ini tidak sesuai dengan penelitian sebelumnya oleh Hansagi et al. (1992) yang menyatakan bahwa triase mempengaruhi kepuasan pasien, hal ini karena kondisi RS Ortopedi Prof. dr. R. Soeharso sebagai RS rujukan nasional relatif jumlah pasien lebih sedikit maka proses triase dapat berjalan optimal sehingga mampu memberikan kepuasan pada pasien. Kondisi pada RS dengan pelayanan umum atau RS dengan tingkat dan jumlah kunjungan yang banyak dapat berimplikasi pada pelaksanaan sistem triase, jumlah kepadatan pasien di IGD, dan waktu tunggu 
pasien sehingga mempengaruhi kepuasan pasien. Penelitian ini menunjukkan bahwa dengan pelaksanaan sistem triase sesuai standar tidak memoderasi pengaruh tanggapan waktu tunggu terhadap kepuasan. Pasien IGD tidak dipengaruhi prioritas kegawatannya secara umum kepuasannya tidak berbeda sehingga secara tidak langsung menunjukkan pelaksanaan sistem triase di IGD RS Ortopedi Prof. dr. R. Soeharso yang salah satu tujuannya yaitu memenuhi kepuasan pasien sudah tercapai.

Belum ada penelitian yang menunjukkan apakah triase ini berperan memperkuat atau memperlemah pengaruh kinerja klinis terhadap kepuasan pasien. Pasien dengan prioritas kegawatan tinggi yaitu dengan kategori triase prioritas 1 dan 2 tentunya memiliki konsekuensi tuntutan dan harapan pasien lebih tinggi terhadap pertolongan medis. Penatalaksanaannya sangat tergantung dari fasilitas dan sumber daya yang tersedia. $\mathrm{Di}$ saat bersamaan kemungkinan terdapat pasien dengan prioritas kegawatan dengan kategori triase prioritas 3 atau 4 yang memiliki prioritas tatalaksana lebih rendah, namun demikian belum tentu berkaitan dengan tuntutan dan harapan pasien terhadap pertolongan medis. Keputusan penempatan pasien sesuai prioritas kegawatan akan memberi implikasi terhadap respon time, waktu tunggu, sumber daya dan fasilitas yang diberikan dalam tatalaksananya. Dari pembahasan di atas hipotesis 10 yaitu prioritas kegawatan pasien sebagai pemoderasi pada pengaruh tanggapan waktu tunggu terhadap kepuasan pasien tidak didukung.

Pada hasil penelitian di RS Ortopedi Prof. dr. R. Soeharso Surakarta menunjukkan bahwa dengan pelaksanaan sistem triase sesuai standar maka tercapai kepuasan pasien/keluarga. Hal ini sesuai dengan tujuan dari pelaksanaan sistem triase tersebut yaitu dalam rangka memenuhi kepuasan pasien. Hasil uji hipotesis baik pada model pengaruh langsung maupun dengan model pemoderasi menunjukkan nilai Adj $\mathrm{R}^{2}<50 \%$ yaitu Adj $\mathrm{R}^{2}$ model pengaruh langsung $42,8 \%$ dan Adj $R^{2}$ model pemoderasi $43,6 \%$. Hal ini menunjukkan masih terdapat faktor lain yang bernilai besar terhadap tingkat kepuasan yang belum diteliti. Hal ini dimungkinkan karena sangat bervariasinya situasi dan kondisi IGD yang selalu dinamis dalam jumlah pasien, kemampuan staf, status sosiodemografis dan kondisi penyakit pasien sendiri. Sehingga diperlukan jumlah responden lebih banyak dengan proporsi yang sesuai untuk masing-masing prioritas kegawatan/triase pasien, adanya berbagai kecenderungan penyakit berbeda pada setiap saat dalam sepanjang tahun, merupakan faktor dinamis yang menjadi tantangan manajemen dalam hal menjaga mutu dan kualitas pelayanan IGD. Selain itu perbedaan jenis $R S$ berdasar tipe $A / B / C / D$ dan tingkat pelayanannya apakah pelayanan umum atau khusus tentu akan berimplikasi terhadap tanggapan responden terhadap kepuasan pasien.

\section{SIMPULAN}

Hasil pengujian pada model membuktikan bahwa tanggapan pada pelayanan perawat, tanggapan pada pelayanan dokter dan tanggapan pada waktu tunggu mempengaruhi kepuasan pasien. Namun tanggapan pada proses registrasi dan instruksi pulang/lanjutan tidak 
mempengaruhi kepuasan pasien. Hipotesis 2, 3 , dan 5 dalam penelitian ini didukung, dan hipotesis 1 dan 4 tidak didukung.

Prioritas kegawatan pasien tidak terbukti sebagai variabel moderasi, sehingga tidak mempengaruhi tanggapan pada registrasi, tanggapan pada pelayanan perawat, tanggapan pada pelayanan dokter, tanggapan pada instruksi lanjutan/pulang dan tanggapan pada waktu tunggu terhadap kepuasan pasien. Hipotesis 6, 7, 8, 9 dan 10 dalam penelitian ini tidak didukung.

Penelitian ini tidak terlepas dari keterbatasan dan kelemahan, di antaranya adalah (1) Data yang diperoleh dari hasil pengisian kuesioner, peneliti tidak dapat mengontrol jawaban dari responden, sehingga terdapat kemungkinan perbedaan persepsi responden dalam memahami konteks pertanyaan instrumen. (2) Kondisi pelayanan gawat darurat yang bervariasi baik dalam hal jumlah pasien, jenis penyakit dan prioritas kegawatannya yang berubah-ubah setiap shift jaga memberi pengaruh terhadap bervariasinya kondisi pasien, keluarga maupun staf yang bertugas. Penelitian hanya diambil dalam waktu bulan Mei dan Juni, dimungkinkan belum mewakili kepuasan pasien yang memiliki kecenderungan jenis penyakit berbeda-beda setiap bulan. (3) RS Ortopedi Prof. dr. R. Soeharso Surakarta merupakan RS rujukan nasional yang sebagian besar kasus rujukan merupakan pasien trauma yang telah mendapatkan pelayanan medis di pelayanan primer. (4) Responden yang mengisi kuesioner di IGD sebagai pintu masuk rawat inap belum mendapatkan seluruh pelayanan utuh dari RS, sehingga dimungkinkan belum dapat memberikan penilaian pelayanan IGD secara lengkap.

Penelitian ini diharapkan mampu memberikan implikasi baik secara teoretis, praktis, maupun metodologis. Melalui ketiga aspek ini diharapkan dapat memberikan pemahaman terkait tanggung jawab ilmiah untuk mengembangkan manajemen operasi dalam rangka meningkatkan kualitas pelayanan IGD. Penelitian ini dilakukan dengan metode yang terstruktur. Metode penelitian yang meliputi instrumen dan pengujian statistik telah teruji melalui prosedur yang baku. Dengan demikian sumber dan kebenarannya dapat dipertanggungjawabkan secara ilmiah. Penggunaan metode ilmiah dalam menganalisa data diperlukan untuk menyelesaikan masalah dan pengambilan keputusan dalam rangka peningkatan mutu pelayanan IGD. Observasi pada penelitian ini berfokus pada kepuasan pasien IGD sehingga generalisasi penelitian bersifat terbatas. Hal ini memberi peluang bagi penelitian lanjutan untuk mengembangkan model dengan konteks yang lebih luas. Peran proses triase sebagai standar pelayanan minimal dalam pelayanan IGD masih memerlukan penelitian lanjutan dengan kondisi yang berbeda berkaitan dengan tipe RS dan jumlah kunjungan pasien yang dapat mempengaruhi pelaksanaan proses triase.

\section{DAFTAR PUSTAKA}

Bjorvell, H, \& Stieg, J. (1991). Patients Perceptions of The Health Care Received In An Emergency Department. Ann Emerg Med. 20:734-8.

Boudreaux, E.D., Ary, R.D., Mandry, C.V., et al. (2000). Determinants of patient 
satisfaction in a large municipal ED: the role of demographic variables, visit characteristics, and patient perceptions. Am J Emerg Med. 18:394-400.

Boudreaux ED, d'Autremont S, Wood K. January (2004). Predictor of Emergency Department Patient Satisfaction: Stability over 17 Months. Academic Emergency Medicine journal. 11(1).

Bursch B, Beezy J, Shaw R. (1993). Emergency department satisfaction: what matters most?. Ann Emerg Med. 22:586-91.

Ekwall A, Gerdtz M, Manias E. (2008). The influence of patient acuity on satisfaction with emergency care: perspectives of family, friends and carers. Journal Clinical Nursing. Mar; 17(6): 800-9. doi: 10.1111/j.1365-2702.2007.02052.x.

Fleming M, Croskerry P. (2009). A Safe Culture in The Emergency Department. In: Croskerry P, Cosby K, Schenkel S, Wears R, eds. Patient Safety in Emergency Medicine. Philadelphia: Lippincott Williams \& Wilkins.

Gujarati, D.N. (2006). Essentials of Econometrics (3 ${ }^{\text {th }}$ Edition). McGraw-Hill International Edition.

Hair, J.F., W.C. Black, B.J. Babin, R.E. Anderson, R.L.Tatham. (2006). Multivariate Data Analysis (6 $6^{\text {th }}$ Edition). New Jersey: Prentice Hall.

Hall MF, Press I. (1996). Keys to patient satisfaction in the emergency department: results of a multiple facility study. Hosp Health Serv Admin. 41, 51532.

Hansagi, H., Carlsson, B., \& Brismar, B. (1992). The urgency of care need and patient satisfaction at a hospital emergency department. Health Care Manage Rev. 17(2), 71-5.

Hedges, JR., Trout A., Magnusson, AR., \& January (2002). Satisfied Patients Exiting the Emergency Department (SPEED).
Study. Academic Emergency Medicine. 9(1).

Heizer Jay, \& Render, B. (2014). Chapter 6. Quality Management and International Standards in Operations Management Sustainability and Supply Chain Management. Eleventh Edition. Person Education, Inc.

Hostutler JJ, Taft SH, Snyder C. (1999). Patient needs in the emergency department. Nurses' and patients' perceptions. J Nurs Admin. 29:43-50.

Jones K, Marsden J, Windle J. (2006). Emergency Triage. Manchester Triage Group. BMJ Books. Blackwell Publishing Ltd.

Lewis KE, Woodside RE. (1992). Patient satisfaction with care in the emergency department. J Adv Nurs. 17:959-64.

Liana Lie. (2009). Penggunaan MRA dengan SPSS untuk Menguji Pengaruh Variabel Moderating Terhadap Hubungan Antara Variabel Independen dan Variabel Dependen. Jurnal Teknologi Informasi DINAMIK. Volume XIV.

Luthans, F. (2005). Organizational Behavior. New York: McGraw-hill.

Nurlaila. (2010). Manajemen Sumber Daya Manusia I. Penerbit LepKhair.

Padma, P., Rajendran, C., \& Lokachari, P. S. (2010). Service Quality and It's Impact on Customer Satisfaction in Indian Hospitals: Perpectives of Patients and Their Attendants. Benchmarking: An International Journal, 17(6), 807-841.

Pohan, I. (2007). Jaminan Mutu Layanan Kesehatan: Dasar-dasar Pengertian dan Penerapan. Jakarta: Penerbit Buku Kedokteran EGC.

Robbins, S.P. (2006). Perilaku Organisasi, PT Indeks, Kelompok Gramedia, Jakarta. 
RS Ortopedi Prof.dr.R.Soeharso Surakarta. (2014). Panduan Triase. IGD RS Ortopedi Prof. dr. R. Soeharso Surakarta.

Rydman, RJ., Roberts, RR., Albrecht, GL., Zalenski, RJ., \& Mc-Dermott, M. (1999). Patient satisfaction with an emergency department asthma observation unit. Acad Emerg Med. 6:178-83.

Sarwono J. (2013). Statistik Multivariat Aplikasi Untuk Riset Skripsi (Edisi 1). Andi Yogyakarta.

Singapore General Hospital. 2000. Triage Concepts. In: Triage Officers Course. Singapore: Department Of Emergency Medicine.

Sugiyono. (2007). Metode Penelitian Administrasi. Bandung,Alfabeta.

Sunyoto Danang. (2009). Analisis Regresi dan Uji Hipotesis. Media Pressindo.

Taufiq S. Tacoh, Jane M. Pangemanan, Jimmy F. Rumampuk. (2013). Hubungan Antara Pelayanan Dokter dengan Kepuasan Pasien di Instalasi Rawat Inap A Badan Layanan Umum Rumah Sakit Umum Pusat Prof. DR. R. D. Kandou Kota Manado. fkm.unsrat.ac.id/wp-content/.../TAUFIQTACOH-091511177.pdf
Taylor C, Benger JR. (2004). "Patient Satisfaction in Emergency Medicine" Emergency Medicine Journal, doi: 10.1136/emj.2002.003723. 21:528-532.

Tjiptono, F. \& Chandra, G. (2011). Service, Quality \& Satisfaction. Yogyakarta: Penerbit Andi.

Trout, A., Magnusson, AR, Hedges, JR. (2000). "Patient satisfaction investigations and the emergency department: what does the literature say?" Acad Emerg Med, 7:695-709.

Waggoner, DM, Jackson, EB, \& Kern, DE. (1981). "Physician influence on patient compliance: a clinical trial" Ann Emerg Med, 10:348-52.

Yarnold, PR., Michelson, EA., Thompson, DA, \& Adams, SL. (1998). "Predicting patient satisfaction: a study of two emergency departments" J Behav Med, 21:545-63.

Zia Tabatabaei, Mohsen R, Riji HM, Abbas E, Mostafa L. (2011). "Patient Satisfaction with Care Received from Emergency Department of Ali-Ebne-Abitaleb Hospital, Iran" Journal of Health Management, 13(1). 1-14. 